\title{
Sociobiology
}

RESEARCH ARTICLE - WASPS

\section{External Morphology of Immatures during the Post-embryonic Development of Mischocyttarus nomurae Richards (Hymenoptera: Vespidae)}

\author{
AA ROCHA ${ }^{1}$, E GIANNOTTI ${ }^{2}$ \\ 1 - Universidade Federal da Bahia (UFBA), Campus Anísio Teixeira, Vitória da Conquista - BA, Brazil \\ 2 - Universidade Estadual Paulista Júlio de Mesquita Filho (UNESP), Rio Claro - SP, Brazil
}

\section{Article History \\ Edited by \\ Marcel G. Hermes, UFPR, Brazil \\ Received $\quad 05$ February 2016 \\ Initial acceptance 17 July 2016 \\ Final acceptance 15 September 2016 \\ Publication date 25 October 2016}

\section{Keywords}

Abdominal Lobe, Spiracles, Larvae, Social wasps, Polistinae.

\section{Corresponding author}

Agda Alves da Rocha,

Universidade Federal da Bahia

Campus Anísio Teixeira

Rua Rio de Contas, Quadra 17, Lote 58, Bairro Candeias, CEP: 45.029-094

Vitória da Conquista - BA, Brasil

E-Mail: rocha.agda@gmail.com

\begin{abstract}
We describe here the immatures of Mischocyttarus nomurae Richards from twenty colonies collected in the municipality of Rio de Contas in the Chapada Diamantina, Bahia State, Brazil. We determined the number of larval instars in post-embryonic development and measured 145 eggs, 353 larvae, 12 prepupae, and 59 pupae. Egg lengths varied from 0.80 to $1.33 \mathrm{~mm}$ and their widths from 0.33 to $0.50 \mathrm{~mm}$. The average rate of growth of the larvae was 1.48. Cephalic capsule widths varied from $0.20-0.43 \mathrm{~mm}$ in the $1^{\text {st }}$ instar larvae, from $0.47-0.63 \mathrm{~mm}$ in the $2^{\text {nd }}$ instar, $0.67-0.83 \mathrm{~mm}$ in the $3^{\text {rd }}$ instar, $0.87-1.20 \mathrm{~mm}$ in the $4^{\text {th }}$ instar, and $1.37-1.73 \mathrm{~mm}$ in the $5^{\text {th }}$ instar larvae. The cephalic capsule of the $1^{\text {st }}$ instar larva was smaller than the width of the egg. The median widths of the $5^{\text {th }}$ instar larvae and the pre-pupae cephalic capsules did not differ significantly. The species has two abdominal lobes that are highly projected forward, and the diameter of first thoracic spiracle is 3.1 times greater than the second. $M$. nomurae shows development patterns typical of the genus.
\end{abstract}

\section{Introduction}

The species Mischocyttarus nomurae was described by Richards in 1978 from two females collected in Fortaleza, Ceará State (CE), Brazil; it was included in the Mischocyttarus cerberus group in a review published by Silveira (2004). The individuals are black, with many pale-yellowish gaster markings, with distinct stripes and frontal margin of the proepisternum distinctly elevated (Richards, 1978). The males of that species were described by Silveira (2004) from samples collected in Lençóis (Chapada Diamantina), Bahia State (BA), Brazil. Among other features, the clypeus is covered by dense recumbent hairs with silvery reflections; the antenna is spirally rolled at the apex, with the last three segments elongated. Souza et al. (2015) recently recorded the occurrence of specimens of $M$. nomurae in Montes Claros, Minas Gerais State (MG), Brazil, captured in traps using passion fruit bait. These are the only references to the species in the literature.
Richards (1978) characterized the larvae of Mischocyttarus de Saussure representatives as having the first abdominal sternite with one, two or three lobes strongly projected, first thoracic spiracle twice as long as the others, and mandibles with only a single elongated tooth. Dias-Filho (1975) studied the $5^{\text {th }}$ instar larvae of several wasp genera and characterized six species of the genus as having the labrum twice as wide as the mentum, tentorial pits located below the level of the antennae, and mandibles ending in a fine, single, curved tooth. Most of the species studied showed larvae with five instars (Giannotti \& Fieri 1991; Giannotti \& Trevisoli 1993; Cecílio et al., 2015) and two showed four instars (Raposo-Filho, 1981; Silva, 1984).

We describe here the external morphologies of the eggs and immatures of Mischocyttarus nomurae Richards during their post-embryonic development, and determine the number of larval instars of that species. 


\section{Material and Methods}

The present study was conducted near the town of Rio de Contas in the Chapada Diamantina ecoregion, in southcentral Bahia State, Brazil (SEI, 2011). The municipality of

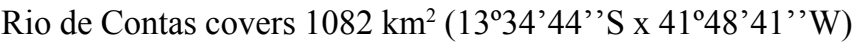
and is located $612 \mathrm{~km}$ from the state capital of Salvador (IBGE, 2015). The regional climate is sub-humid to dry, with a mean annual temperature of $19.1^{\circ} \mathrm{C}$ and mean annual rainfall rate of $813.2 \mathrm{~mm}$ (SEI, 2011).

Twenty colonies were collected in February/2013 without adults, and were subsequently maintained in plastic flasks. Following their sacrifice at low temperatures, the immatures were removed from the nest cells (using tweezers and a desk magnifying glass) and then fixed in Dietrich solution for $48 \mathrm{~h}$ and preserved in $70 \%$ alcohol.

Eggs, larvae, pre-pupae and pupae were measured under a stereoscopic microscope, with the aid of an ocular micrometer, in the Zoology Laboratory of the Federal University of Bahia, Campus Anísio Teixeira (IMS-CAT-UFBA). The following aspects were examined: 1) the largest widths and lengths of the eggs; 2) the greatest widths of cephalic capsules of the larvae, pre-pupae and pupae; and 3) the diameters of the first two spiracles of the last instar larvae (Giannotti \& Silva, 1993; Giannotti, 1995; 1998; Prezoto \& Gobbi, 2005).

Photographic records of immatures and the cephalic capsules were made using a digital camera coupled to a stereoscopic microscope in the Zoology Department of the Júlio de Mesquita Filho State University of São Paulo (UNESP-Rio Claro).

Scanning electron microscopy of prepared samples of larvae of $5^{\text {th }}$ instar was undertaken in December/2014 at the Gonçalo Moniz Research Center of the Oswaldo Cruz Research Foundation (FIOCRUZ) in Salvador, Bahia (BA), Brazil. The samples were prepared according to standard protocols used at that research center: five colony samples were fixed in a $2 \%$ glutaraldehyde solution in $0.1 \mathrm{M}$ sodium cacodylate buffer ( $\mathrm{pH}$ 7.4) for $2 \mathrm{~h}$ at room temperature, and subsequently rinsed in $0.1 \mathrm{M}$ sodium cacodylate buffer $(\mathrm{pH}$ 7.4) (3 rinses of 5 minutes each, at room temperature). The samples were then post-fixed in $1 \%$ osmium tetroxide in 0.1 $\mathrm{M}$ sodium cacodylate buffer for $1 \mathrm{~h}$ at room temperature, and subsequently rinsed again with $0.1 \mathrm{M}$ sodium cacodylate buffer ( $\mathrm{pH}$ 7.4) (3 rinses of 10 minutes each, at room temperature). The samples were then dehydrated in an ethanol series $(30 \%, 50 \%$, $70 \%, 90 \%$ and $100 \%$ for 40 min. each) and then submitted to critical point drying. After this procedure, the specimens were mounted on stubs, sputter coated with gold, and observed using a JEOL 6390LV scanning electron microscope.

The growth rates of the larvae were calculated (Dyar, 1890), and the non-normally distributed quantitative variables were compared among eight groups using the nonparametric Kruskal-Wallis test, followed by Dwass-Steel-CritchlowFligner post hoc test to obtain the adjusted p-values for each pairwise comparison in multiple-group analyses. Normality was assessed by visual inspection of histogram plots and using the Shapiro-Wilk normality test. All statistical analyses were performed with R Statistical Software (R Development Core Team, 2011). A p-value of $<0.05$ was considered to be statistically significant, and all reported p-values are two-sided.

\section{Results and Discussion}

Morphometry and Larval Instars. 145 eggs, 353 larvae, 12 pre-pupae, and 59 pupae from twenty colonies were measured and characterized. The eggs, with narrow and transparent chorion, had an average length of $1.03 \pm 0.12 \mathrm{~mm}$ $(\mathrm{n}=145,0.80-1.33 \mathrm{~mm})$ and an average width of $0.40 \pm 0.03$ $\mathrm{mm}(\mathrm{n}=145,0.33-0.50 \mathrm{~mm})($ Table 1$)$. The $1^{\text {st }}$ instar larvae differed in width from the eggs, being smaller $(\mathrm{p}<0.0001$; Dwass-Steel-Critchlow-Flignertest) (Table 1, Fig 1). This pattern was similar to that reported for $P$. lanio (Fabricius) (Giannotti, 1995) and differed from three other species of the genus that showed $1^{\text {st }}$ instar larvae with dimensions similar to egg diameters: M. cassununga (Giannotti \& Fieri, 1991), M. drewseni (Giannotti \& Trevisoli, 1993), and M. latior (Cecílio et al., 2015). The eggs were attached either to the side wall of the cell (Giannotti \& Silva, 1993), or at the angle formed between two walls (Giannotti, 1995 and Prezoto and Gobbi, 2005).

The larvae specimens showed five instars, with differences in the median widths between the five groups $(\mathrm{p}<0.0001$, Kruskal-Wallis test) (Table 1, Fig 1, Fig 2). This is similar to the situation observed with M. cassununga (von Ihering) (Giannotti \& Fieri, 1991), M. drewseni Saussure (Giannotti \& Trevisoli, 1993), and M. latior (Fox) (Cecílio et al., 2015). Other species of other genera likewise follow this pattern, such as Agelaia Lepeletier (Giannotti, 1988), Brachygastra Perty (Machado et al., 1988), Polistes Latreille (Giannotti, 1995; 1997; Prezoto \& Gobbi, 2005), Polybia Lepeletier (Tech \& Machado, 1989; Carvalho \& Silva, 1975; Solis et al., 2012), and Protopolybia Ducke (Silveira, 1994). Giannotti and Fieri (1993) associated high numbers of instars to the long post-embryonic development of social wasps. It is

Table 1 - Descriptive statistics of the widths ( $\mathrm{mm}$ ) of the eggs and the cephalic capsules of the larvae (L1 - L5), pre-pupae (PP), and pupae (P) of Mischocyttarus nomurae (Hymenoptera, Vespidae).

\begin{tabular}{ccccccccc}
\hline Immatures & $\mathbf{n}$ & Mean & SD & $\mathbf{9 5 \%}$ CI & Median & IQR* $^{*}$ & Min Max \\
\hline Egg & 145 & 0.40 & 0.03 & $(0.39 ; 0.40)$ & 0.40 & $(0.40 ; 0.40)$ & 0.33 & 0.50 \\
L1 & 90 & 0.33 & 0.04 & $(0.32 ; 0.34)$ & 0.33 & $(0.33 ; 0.33)$ & 0.20 & 0.43 \\
L2 & 46 & 0.51 & 0.04 & $(0.50 ; 0.53)$ & 0.50 & $(0.50 ; 0.53)$ & 0.47 & 0.63 \\
L3 & 54 & 0.72 & 0.05 & $(0.71 ; 0.74)$ & 0.71 & $(0.67 ; 0.77)$ & 0.67 & 0.83 \\
L4 & 53 & 1.03 & 0.07 & $(1.01 ; 1.05)$ & 1.03 & $(1.00 ; 1.07)$ & 0.87 & 1.20 \\
L5 & 110 & 1.60 & 0.08 & $(1.58 ; 1.61)$ & 1.60 & $(1.57 ; 1.67)$ & 1.37 & 1.73 \\
PP & 12 & 1.58 & 0.07 & $(1.53 ; 1.62)$ & 1.60 & $(1.52 ; 1.63)$ & 1.47 & 1.67 \\
P & 59 & 1.85 & $0.07(1.83 ; 1.87)$ & 1.83 & $(1.80 ; 1.93)$ & 1.67 & 2.03 \\
\hline
\end{tabular}

*Interquartile Range 
therefore probable that the development time of $M$. nomurae is longer than that of M. atramentarius Z. (Silva, 1984) and M. extinctus Z. (Raposo-Filho, 1981), which develop four instars, although that has not been directly studied.

The average growth rate of the larvae was 1.48 (1.57 between L1 and L2, 1.38 between L2 and L3, 1.43 between L3 and L4, and 1.55 between L4 and L5). The highest rate, between $\mathrm{L} 1$ and $\mathrm{L} 2$, is similar to that observed in $M$. latior (Cecílio et al., 2015). The average growth rate is in accordance with Dyar's rule. The species showed a higher average growth rate than the other species of the genus. The ascending order of growth was:1.37 in M. latior (Cecílio et al., 2015), 1.38 in M. drewseni (Giannotti \& Trevisoli, 1993), 1.42 in M. atramentarius and M. cassununga (Silva, 1984; Giannotti \& Fieri 1991, respectively), and 1.46 in M. extinctus (Raposo-Filho, 1981).

No differences were observed in the median width values among $5^{\text {th }}$ instar and pre-pupae cephalic capsules $(p=0.957$; Dwass-Steel-Critchlow-Fligner test). The elongated $5^{\text {th }}$ instar larva is considered pre-pupae, not an instar. The data on the widths of the pupae cephalic capsules are shown in Table 1 and Fig 1.

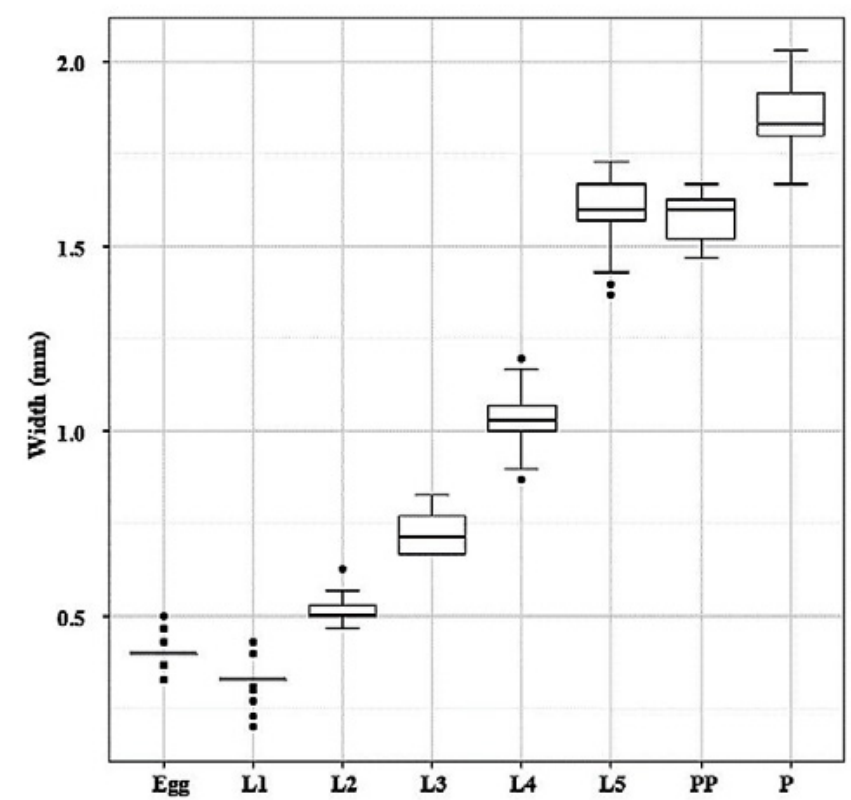

Fig 1. Box plots representing the widths $(\mathrm{mm})$ of the eggs and the cephalic capsules of the larvae (L1 - L5), pre-pupae (PP), and pupae (P) of Mischocyttarus nomurae (Hymenoptera: Vespidae).

General Morphology. Like the other species of wasps studied by Dias-Filho (1975), the vermiform larvae of $M$. nomurae had a light-yellow color, thorax with three segments, and abdomen with 10 segments. The abdomen showed a pair of dorsal crests on each segment, ventral lobes, and lateral humps arranged below the spiracle line (Fig 2-A: L5).

The anal slot, which is transversal, is found on last segment (the anal segment) (Fig 3-G). The L1 kept the chorion of the egg and the L2 to L4 larvae kept the exuviae of the previous instar fixed to the final portion of the abdomen
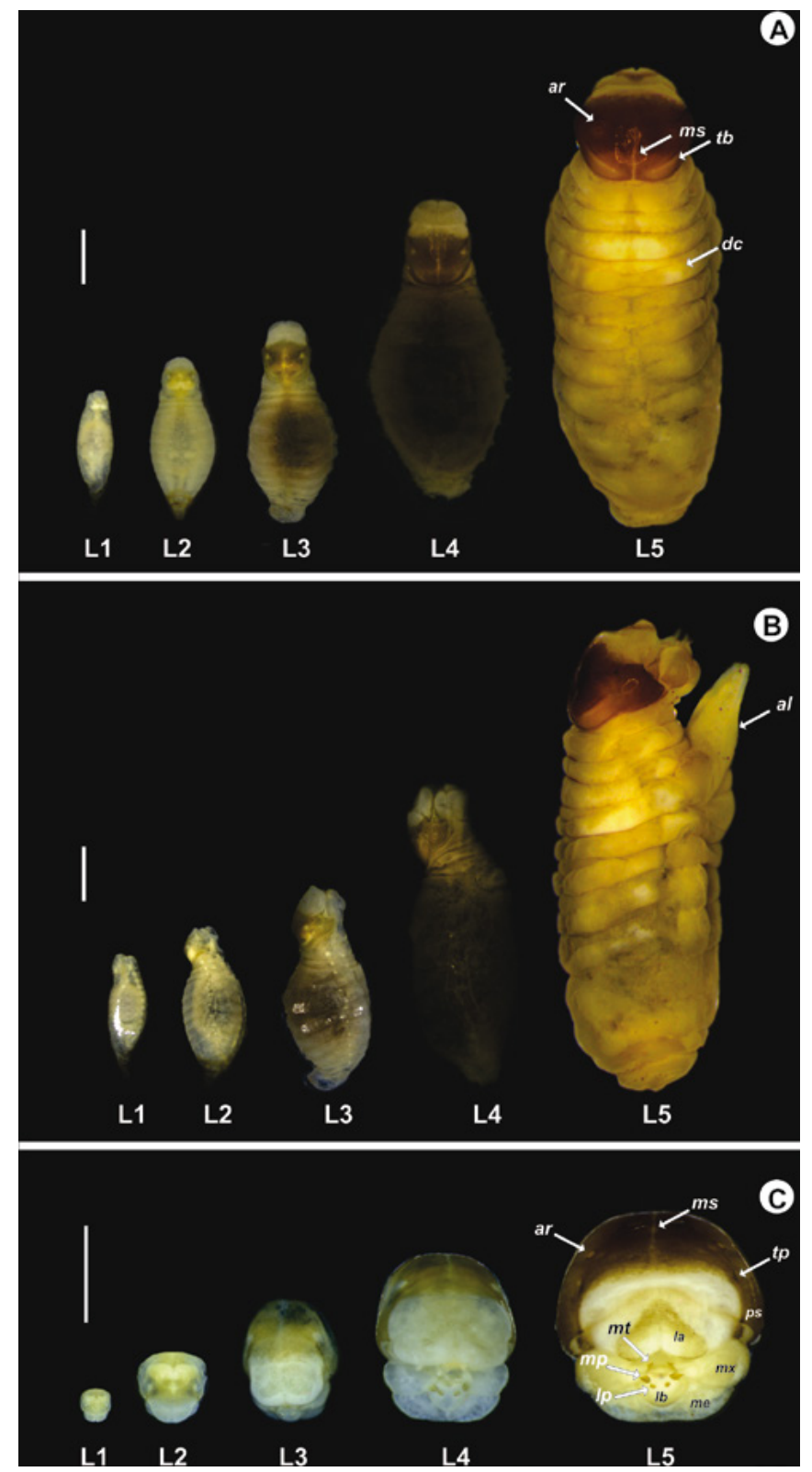

Fig 2. Dorsal (A), lateral (B) views of larvae and frontal view of cephalic capsules (C) of Mischocyttarus nomurae (Hymenoptera, Vespidae): (L1 - L5) - $1^{\text {st }}$ to $5^{\text {th }}$ instar larvae, respectively. al abdominal lobe, $\boldsymbol{a r}$ - antenna ring, $\boldsymbol{d c}$ - dorsal crest, $\boldsymbol{l a}$ - labrum, $\boldsymbol{l i}$ - labium, $\boldsymbol{l} \boldsymbol{p}$ - labial papilla, $\boldsymbol{m} \boldsymbol{e}$ - mentum, $\boldsymbol{m} \boldsymbol{p}$ - maxillary papilla, $\boldsymbol{m} \boldsymbol{s}$ - median suture, $\boldsymbol{m t}$ - mandible tooth, $\boldsymbol{m x}$ - maxilla, $p \boldsymbol{s}-$ pleurostome, $\boldsymbol{t} \boldsymbol{b}$ - temporal band, $\boldsymbol{t} \boldsymbol{p}$ - tentorial pit. Scale bar: $1 \mathrm{~mm}$.

(that served as the attachment to the cell wall) (Figs 2-B and $3-\mathrm{H})$. This differs from the L5 larvae, which are fixed to the cell wall by the dorsal crests and lateral humps.

The head, formed by the cephalic capsule and buccal pieces, is more sclerotized in L5 larvae. It has a median suture and a pair of temporal bands that are seen in all instars (Fig 2-A). The tentorial pits are located below the level of the antennae sockets and in the upper portion of the lateral margins of the clypeus (Fig 2-C), as was observed by Dias-Filho (1975) for other species of Mischocyttarus. The 
mandible is covered by the bilobate labrum in all of the instars, with only a single tooth, this being elongated, falcate, and thin, as is typical for the genus (Dias-Filho 1975; Giannotti \& Silva, 1993). Both the pair of maxilla and the labium have a pair of elongated brownish papillae (Fig 2-C and 3-B).

The ten spiracles can be seen in Fig 3 (Larva L5). The first spiracle of the L5 larvae (located between the prothorax and the mesothorax) has a diameter of $0.26 \mathrm{~mm} \pm 0.04(\mathrm{n}=47$, $012-032 \mathrm{~mm}$ ), being 3.1 times larger than the second thoracic spiracle (between the mesothorax and the metathorax; 0.08 $\pm 0.01 \mathrm{~mm}[\mathrm{n}=47,0.06-0.09 \mathrm{~mm}]$ (Fig 3-A to 3-D). It is therefore twice the diameter of the other spiracles (Richards, 1978). The other spiracles have similar diameters, with the third to the tenth being located in the $1^{\text {st }}$ to the $8^{\text {th }}$ abdominal segments respectively (Fig 3A, 3G).

The species shows two abdominal lobes on the first abdominal sternite that are strongly projected forward. They can be seen as small protuberances in L3, still little developed in L4, and fully developed in L5 (Fig 2-B). According to Silveira (2008), this character is widely observed in several
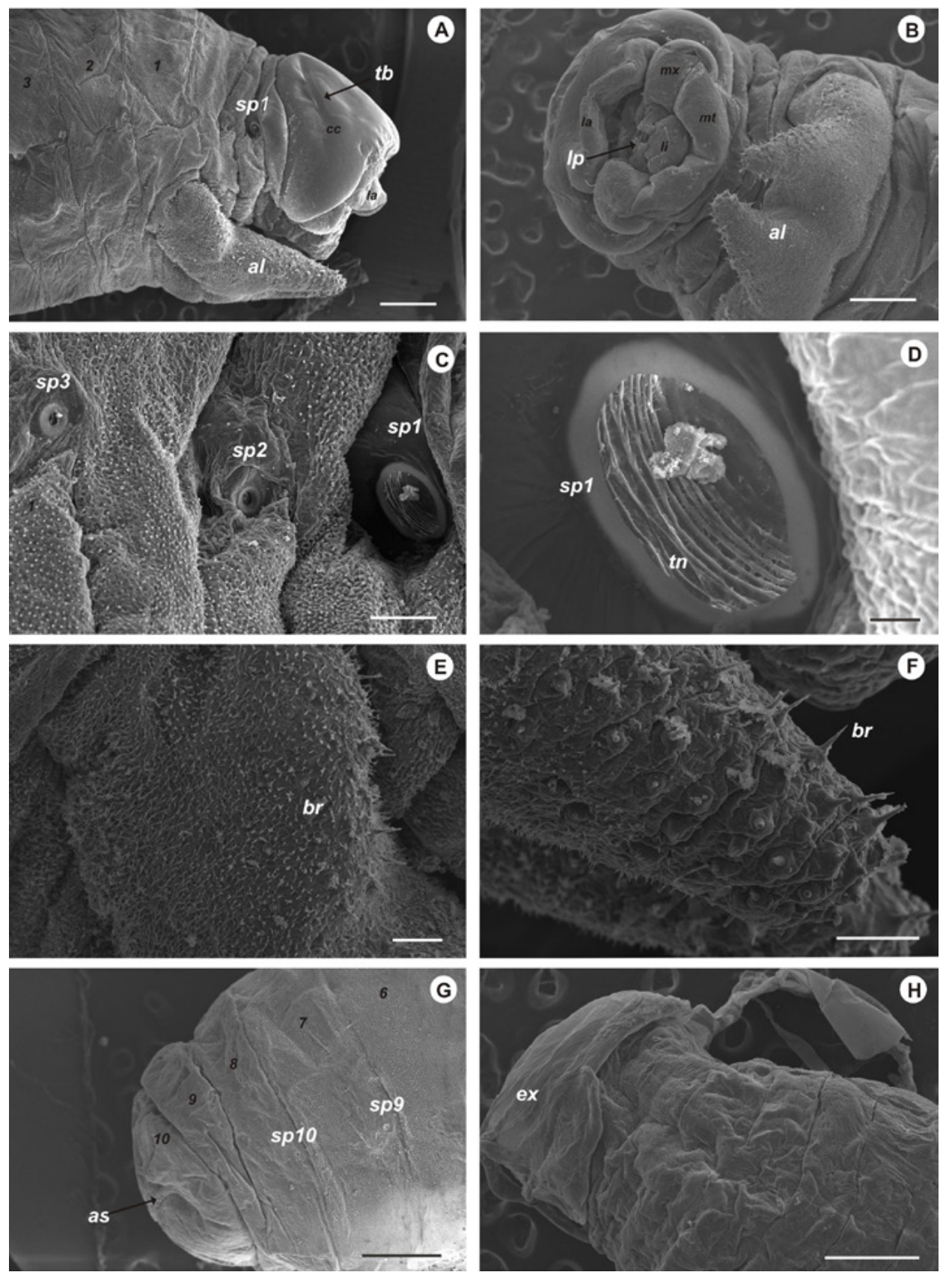

Fig 3. Larva 5 (A to $\mathrm{G}$ ) and Larva $4(\mathrm{H})$ of Mischocyttarus nomurae (Hymenoptera, Vespidae): A - side view of the frontal region; B ventral view of the frontal region; $\mathrm{C}$ - detail of the spiracles; $\mathrm{D}$ - detail of the $1^{\text {st }}$ spiracle; $\mathrm{E}$ - basal portion of the right side abdominal lobe; $\mathrm{F}$ - apical portion of the right side abdominal lobe; $\mathrm{G}$ - detail of posterior region; $\mathrm{H}$ - detail of posterior region. al - abdominal lobe, as anal slot, $\boldsymbol{b} \boldsymbol{r}$ - bristles of lobes, $\boldsymbol{c} \boldsymbol{c}$ - cephalic capsule, $\boldsymbol{e x}$ - exuviae; $\boldsymbol{l} \boldsymbol{a}$ - labrum, $\boldsymbol{l}$ - labium, $\boldsymbol{l} \boldsymbol{p}$ - labial papilla, $\boldsymbol{m \boldsymbol { t }}$ - mentum, $\boldsymbol{m \boldsymbol { x }}-\mathrm{maxilla}$, $\boldsymbol{s p} 1$ - spiracle between the prothorax and the mesothorax, $\mathbf{s p 2}$ - spiracle between the mesothorax and the metathorax, $\mathbf{s p 3}$ - spiracle of the $1^{\text {st }}$ abdominal segment, $\mathbf{s p} 9-9^{\text {th }}$ spiracle, $\mathbf{s p 1 0}-10^{\text {th }}$ spiracle, $\boldsymbol{t} \boldsymbol{b}-$ temporal band, $\boldsymbol{t} \boldsymbol{n}$ - taenidia. Numbers in black indicate the abdominal segments. Scale bar: A, B, G, H = 500 $\mu \mathrm{m} ; \mathrm{C}, \mathrm{E}, \mathrm{F}=100 \mu \mathrm{m} ; \mathrm{D}=20 \mu \mathrm{m}$. 
subgenera of Mischocyttarus. The fact that $M$. nomurae bears two lobes differs it from $M$. latior, which has only a single lobe on the first abdominal sternite - this being a character of the subgenus Kappa. These lobes are vestigial in the second instar larvae of $M$. latior, and also in the third instar of $M$. drewseni (Giannotti \& Trevisoli 1993; Silveira, 1998; Cecílio et al., 2015).

The lobes show ornamentations on their cuticles and bristles that increase in density from the base to the apex, what could indicate a sensorial function (Fig 3-A, 3-B, 3-E, 3-F). Giannotti and Silva (1993) disagreed with the suggestions of Reid (1942) and Wheeler and Wheeler (1979) that the lobes could be used to hold food before its ingestion, as they observed that the workers of $M$. cassununga delivered already macerated food directly to the buccal parts of the larvae. Jeanne (1972) reported larvae of $M$. drewseni using those lobes to help pump larval saliva to adults that had solicited it. Hunt (1988) designated this behavior "lobe erection". Detailed studies of lobe ultrastructure have not yet been undertaken that could shed more light on its function(s).

As observed in $M$. cassununga and $M$. drewseni, the transparent cuticle of the elongated pre-pupae allows the thoracic appendixes of the pharate pupa (Giannotti \& Silva, 1993; Giannotti \& Trevisoli, 1993), and sometimes their compound eyes (Giannotti, 1995), to be seen. The lobes are now strongly projected rearwards as the larva prepares to metamorphosis (Fig 4-A).
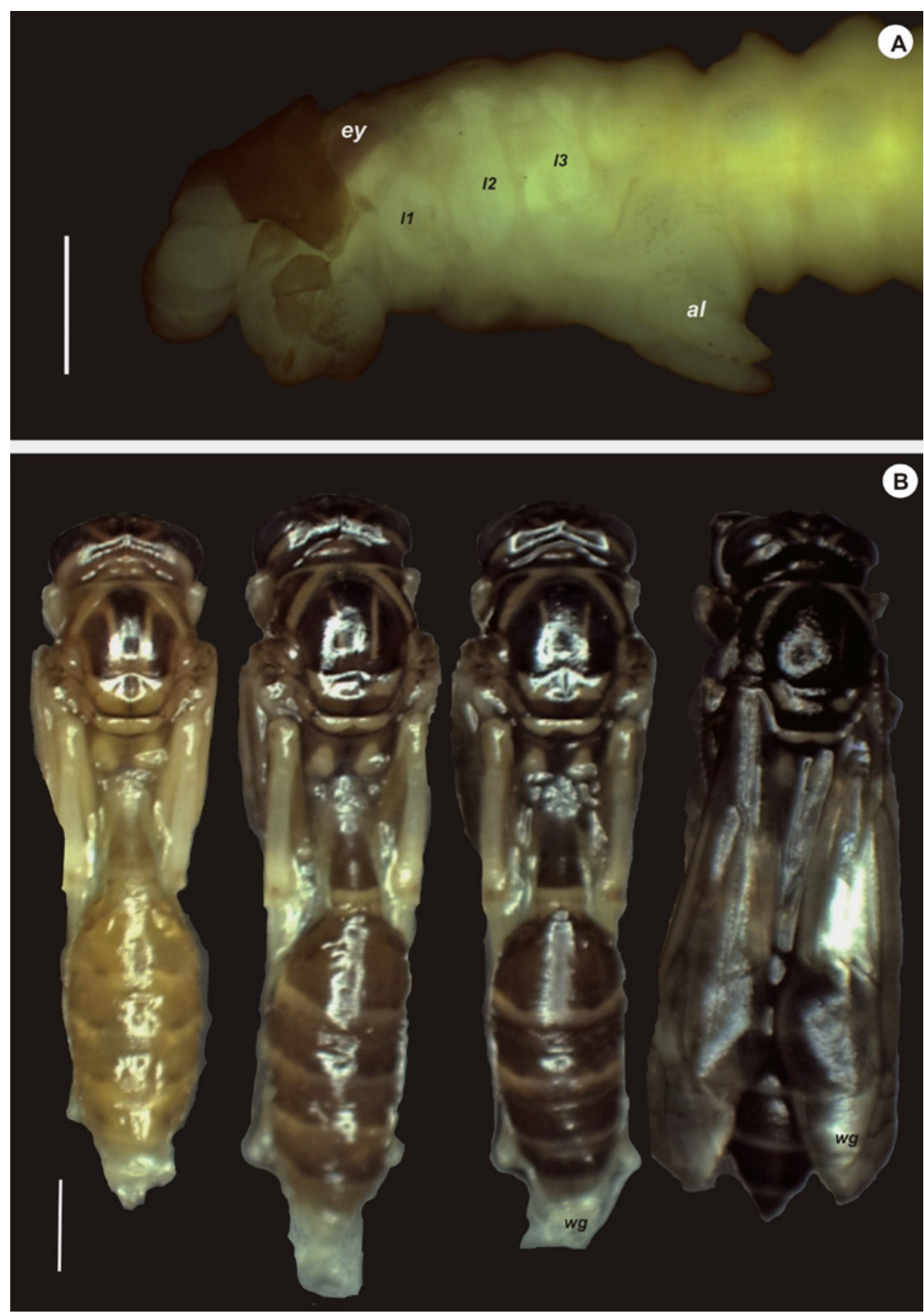

Fig 4. Lateral view of a pre-pupa (A) and dorsal view of a pupa (B) of Mischocyttarus nomurae (Hymenoptera, Vespidae). al - abdominal lobe, $\boldsymbol{e y}$ - compound eye, $\boldsymbol{l} \boldsymbol{1}$ - protothoracic leg, $\boldsymbol{l} \mathbf{2}$ - mesothoracic leg, $\boldsymbol{l 3}$ - metathoracic leg, $\boldsymbol{w g}$ - wing. Scale bar: $1 \mathrm{~mm}$. 
The pupae become graded in color from milky white to dark as they became older, also becoming more sclerotized. Darkening initiated in the head and then advanced towards the thorax, while the eyes likewise darkened from reddish to dark brown, as had been reported for $P$. lanio (Giannotti, 1995). The wings, which were shaped like filaments below the gaster, then became free and positioned over the gaster (Fig 4-B).

Thus, with the exception of the $1^{\text {st }}$ instar larva, which is much smaller than the egg, M. nomurae shows development patterns typical of the genus: with the presence of abdominal lobes strongly projected forward, but only fully developed in the $5^{\text {th }}$ instar; mandibles with a single elongated tooth; and the first spiracle twice the diameter of the others, as reported by Richards (1978).

\section{Acknowledgements}

The authors thank Fabio Akashi Hernandes for his valuable support in the photographic registrations of the larvae, and for lending us the digital camera and stereoscopic microscope set up; Frederico Moreira for statistical support; and the team at FIOCRUZ, in Salvador, Adriana Lanfredi Rangel, Maria Lúcia Vieira Moreno, and Cláudio Pereira Figueira for their attention and guidance in performing the scanning microscopy.

\section{References}

Carvalho, G.G.\& Silva, M.T. (1975). Alguns aspectos do desenvolvimento larval de Polybia paulista Richards (Hymenoptera: Vespidae). Studia Entomológica, 8: 555-568.

Cecílio, D.S.S., Da Rocha, A.A. \& Giannotti, E. (2015). Post-embryonic Development of Mischocyttarus latior (Fox) (Hymenoptera: Vespidae). Sociobiology, 62: 446-449. doi: 10.13102/sociobiology.v62i3.400.

Cumber, R.A. (1951). Some observations on the biology of the Australian wasp Polistes humilis Fabr. (Hymenoptera, Vespidae) in North Auckland (New Zealand) with special reference to the nature of worker caste. Proceedings of the Royal Entomological Society of London, 26: 11-16.

Dias-Filho, M.M. (1975). Contribuição à Morfologia de Larvas de Vespídeos sociais do Brasil (Hymenoptera, Vespidae). Revista Brasileira de Entomologia, 19: 1-36.

Dyar, H.G. (1890). The number of molts of lepidopterous larvae. Psyche, 5: 420-422.

Giannotti, E. (1995). Immature Stages of Polistes lanio (Fabricius, 1775) (Hymenoptera, Vespidae). Revista Brasileira de Biologia, 55: 527-531.

Giannotti, E. (1997). Biology of the Wasp Polistes (Epicnemius) cinerascens Saussure (Hymenoptera: Vespidae). Anais da Sociedade Entomológica do Brasil, 26: 61-67.

Giannotti, E. (1998). On the nest of Agelaia multipicta (Haliday,
1836) and description of the mature larva (Hymenoptera, Vespidae). Revista Brasileira de Entomologia, 42: 97-99.

Giannotti, E. \& Fieri, S.R. (1991). On the brood of Mischocyttarus (Monocyttarus) cassununga (Ihering, 1903) (Hymenoptera, Vespidae). Revista Brasileira de Entomologia, 35: 263-267.

Giannotti, E. \& Silva, C.V. (1993). Mischocyttarus cassununga (Hymenoptera, Vespidae): external morphology of the brood during the post-embryonic development. Revista Brasileira de Entomologia, 37: 309-312.

Giannotti, E. \& Trevisoli, C. (1993). Desenvolvimento pósembrionário de Mischocyttarus drewseni Saussure, 1857 (Hymenoptera, Vespidae). Insecta, 2: 41-52.

Hunt, J.H. (1988). Lobe erection behavior and its possible social role in larvae of Mischocyttarus paper wasps. Journal of Insect Behavior, 1: 379-386.

Instituto Brasileiro de Geografia e Estatística (2015). IBGE. Cidades: Bahia, Rio de Contas. Retrieved from: http://cod. ibge.gov.br/1DWF.

Jeanne, R.L. (1972). Social biology of the Neotropical Wasp Mischocyttarus drewseni. Bulletin of the Museum of Comparative Zoology, 144: 63-150.

Machado, V.L.L., Gravena, S. \& Giannotti, E. (1988). Análise populacional e morfométrica em uma colônia de Brachygastra lecheguana (Latreille, 1824) na fase reprodutiva. Anais da Sociedade Entomológica do Brasil, 17: 491-506.

Prezoto, F. \& Gobbi, N. (2005). Morfometria dos estágios imaturos de Polistes simillimus Zikán, 1951 (Hymenoptera, Vespidae). Revista Brasileira de Zoociências, 7: 47-54.

Raposo-Filho, J.R. (1981). Biologia de Mischocyttarus (Monocyttarus) extinctus Zikán, 1935 (Polistinae - Vespidae). (Master's Dissertation). Rio Claro: IB-UNESP, 163p.

R Development Core Team (2011). R: A language and environment for statistical computing. R Foundation for Statistical Computing, Vienna, Austria. ISBN 3-900051-070. Retrieved from: https://www.r-project.org/.

Reid, J.A. (1942). On the classification of the larvae of the Vespidae (Hymenoptera). Transactions of the Entomological Society of London, 92: 285-331.

Richards, O.W. (1978). The social wasps of the Americas excluding the Vespinae. London: British Museum (Natural History), 580p.

SEI - Superintendência de Estudos Econômicos e Sociais da Bahia. (2011). Estatística dos municípios baianos - Volume 15: Território de Identidade Chapada Diamantina. Salvador: SEI, $434 \mathrm{p}$.

Silva, M.N. (1984). Aspectos do desenvolvimento e do comportamento de Mischocyttarus (Kappa) atramentarius 
Zikan, 1949 (Hymenoptera - Vespidae) (PhD Thesis). Rio Claro: IBUNESP, 151p.

Silveira, O.T. (1994). External morphology of the larva of Pseudochartergus chartergoides (Gribodo) (Hym.,Vespidae, Polistinae). Entomologist's Monthly Magazine, 130: 71-76.

Silveira, O.T. (1998). Mischocyttarus (Mischocyttarus) aripuanaensis. A new social wasp from western-central Brazil, and redescription of Mischocyttarus lindigi Richards (Hymenoptera, Vespidae, Polistinae). Papéis Avulsos de Zoologia, 40: 359-367.

Silveira, O.T. (2004). The male of Mischocyttarus nomurae Richards, with a re-examination of the limits and contents of the M. cerberus species group (Hymenoptera, Vespidae, Polistinae, Mischocyttarini). Revista Brasileira de Entomologia, 48: 335-338.

Silveira, O.T. (2008). Phylogeny of wasps of the genus Mischocyttarus de Saussure (Hymenoptera, Vespidae, Polistinae). Anais da Sociedade Entomológica do Brasil, 26: 61-67.
Solis, D.R.; Dias, N.B. \& Fox, E.G.P. (2012). External Morphology of the Immatures of Polybia paulista (Hym., Vespidae). Florida Entomologist, 95: 890-899. doi: 10.16 53/024.095.0411.

Souza, M.M., Pires, E.P., Eugênio, E. \& Silva-Filho, R. (2015). New Occurrences of Social Wasps (Hymenoptera: Vespidae) in Semideciduous Seasonal Montane Forest and Tropical Dry Forest in Minas Gerais and in the Atlantic Forest in the State of Rio de Janeiro. EntomoBrasilis, 8: 6568. doi:10.12741/ebrasilis.v8i1.359

Tech, G.M. \& Machado, V.L.L. (1989). Análise morfométrica em colônias de Polybia (Myraptera) fastidiosuscula Sassure, 1854 (Hymenoptera, Vespidae). Revista Brasileira de Entomologia, 33: 447-454.

Wheeler, G.C. \& Wheeler, J. (1979). Larvae of the social Hymenoptera. In H.R. Hermann (Ed.), Social Insects (pp. 287-338). New York: Academie. 